\title{
Studies on the removal of metal ions from aqueous solution using Immobilized Bombax costatum calyx
}

\author{
S.A.Osemeahon ${ }^{1}$, J.T. Barminas ${ }^{1}$ and M.A. Hamma ${ }^{1}$ Adama $^{2}$ \\ ${ }^{I}$ Department of Chemistry, Modibbo Adama University of Technology, PMB 2076, Yola Nigeria \\ ${ }^{2}$ Department of Chemistry, Federal College of Education PMB 2042, Yola Nigeria
}

\begin{abstract}
The sorption capacity of Immobilized Bombax costatum calyx (IBCC) for the removal of metal ions $\left(\mathrm{Fe}^{3+}, \mathrm{Pb}^{2+}, \mathrm{Zn}^{2+}, \mathrm{Cr}^{3+}\right.$ and $\left.\mathrm{Cd}^{2+}\right)$ was studied using batch experiments. The residual metal ion concentrations were investigated using Atomic Absorption Spectrophotometer ( AAS). The influence of factors such as contact time, initial concentration, ionic strength, $p H$ and temperature were investigated. The metal ion sorption capacity by IBCC decreases with increasing ionic strength but increases with increasing $\mathrm{pH}$ value and initial metal ion concentration. The sorption rate for the metal ions were rapid for the first 30 minutes and equilibrium was established within $2 \mathrm{hrs}$. The maximum sorption capacity for $\mathrm{Fe}^{3+}, \mathrm{Pb}^{2+}, \mathrm{Cd}^{3+}, \mathrm{Cr}^{2+}$, and $\mathrm{Zn}^{2+}$ were found to be 98.65, 96.36, 90.57, 84.38 and 80.28 respectively. From this experiment, it is showed that the abundant but presently wasted Bombax Costatum calyx could be turned into an environmentally friendly and cost effective sorbent for the removal of heavy metal ions from waste water.
\end{abstract}

Key words; Aqueous solution, Heavy metal ions, Immobilized Bombax costatum calyx, Sorption capacity.

\section{Introduction}

Due to industrial activities, contamination of the environment by heavy metals has become a serious problem [1]. Many of these toxic metals enter the environment through fossil fuel combustion as well as mining and smelting process [2]. The natural process of metal transportation between the soil and water concentrates heavy metal contamination in the environment [3]. Once in the environment, metals are difficult to remediate and can adversely impact human health [4]. Even in low doses, metals which do not have distinguishable odour and colour characteristics, still pose a major threat [5-6]. Current technologies for cleaning up heavy-metals contaminated soils involve excavation and reburial in landfills [7]. This process is expensive and usually reserved for small areas, and the metals are still not isolated from the environment [8]. Contaminated waters are typically detoxified through the use of ion exchange and activated charcoal filters which are not only costly, but nonselective for heavy metals removal [9]. Due to the high cost of these methods, there is need for the development of a more cost-effective method.

Bioremediation has emerged as an inexpensive solution. Many researchers have studied the use of live microbial systems for the purpose of remediating contaminated waters [10-14]. A few plant species have shown a remarkable resistance to heavy metals such as copper, zinc, and lead [15-16]. Phyto-chelations and proteins within the plant may be produced in large concentration to bind the metals and reduce their harmful effects [17]. Therefore, plants that grow in contaminated areas should show a greater ability to recover heavy metals and may be a good source for naturally occurring biological compounds that have potential for the remediation of contaminants [18].

Conventional methods of heavy metals removal from wastewaters, including ion exchange,chemicalprecipitation,coagulation/flocculation,complexation/sequestration, electrochemical operations, biological treatment, ultrafiltration, or electrochemical deposition, do not seem to be economically feasible for water and wastewater treatment because of their relatively high costs or difficulty to implement in developing countries [19]. Therefore, the need exists for a treatment strategy that is simple and robust and that addresses local resources and constraints [20]. Sorption operations, including adsorption and ion exchange, are a potential alternative for water and wastewater treatment [21]. Adsorption has advantages over other methods. The design is simple, and it is sludge free and can involve low investment in terms of both the initial cost and land [22].

Activated sludge is used as bioadsorbent for $\mathrm{Cu}^{2+}, \mathrm{Cd}^{2+}$ and $\mathrm{Ni}^{2+}$. Pretreatment with $\mathrm{NaOH}$ was found to improve the adsorption capacity of the sludge, whereas treatment with $\mathrm{HCl}$ reduces it [23]. Anaerobic sludge supplied from a wastewater treatment plant, acts as a novel biosorbent, for $\mathrm{Pb}^{2+}, \mathrm{Cu}^{2+}, \mathrm{Cd}^{2+}$, and $\mathrm{Ni}^{2+}$ removal from aqueous solutions [24]. Rice husk, a surplus agricultural byproduct, is used for the sorption of $\mathrm{Cd}^{2+}$ from aqueous solution. Some simple and low-cost chemical modifications resulted in increasing the sorption capacity of raw rice husk (RRH) have been studied [25]. Papaya wood was evaluated as a new biosorbent of heavy metal ions such as $\mathrm{Cu}^{2+}, \mathrm{Cd}^{2+}$ and $\mathrm{Zn}^{2+}$ [26]. The sorption of lead, copper, cadmium, zinc and nickel by marine algal and characterization of biosorptive capacity were significantly affected by solution $\mathrm{pH}$ [27]. Coffee residues 
binding with clay as adsorbent (hereafter called CC-adsorbent) are utilized for removal of heavy metal ions in solution [28]. Cocoa shells (CS) have been identified as a very efficient natural sorbent to remove $\mathrm{Pb}^{2+}$ and other metal ions from acid soil leachates (ASL) [29]. Fungal biomass immobilized within a loofa sponge (FBILS) is used as a new biosorbent system to remove heavy metal ions such as $\mathrm{Pb}^{2+}, \mathrm{Cu}^{2+}$ and $\mathrm{Zn}^{2+}$ from aqueous solution [30]. Calcined phosphate is a good adsorbent for the removal of $\mathrm{Pb}^{2+}, \mathrm{Cu}^{2+}$, and $\mathrm{Zn}^{2+}$ from solutions. The abundance of natural phosphate, its low price and non-aggressive nature towards the environment are advantages for its utilization in the point of view of wastewater and wastes clean up [31].

Although live biological systems work well for low concentrations, they cannot survive the high levels that are found in seriously contaminated areas and industrial influents [32]. The use of non-living biomaterial containing metals-binding compounds would have the advantage of non requiring care and maintenance as well as being useful in remediating areas with high levels of contaminants that would otherwise kill live systems [33]. Hence a plant such as Bombax Costatum that grow very well in contaminated areas should show a greater ability to recover heavy metals and may be a good source for naturally occurring biological compounds that have potential for contaminant remediation might contain natural metal binding compounds and could be a possible source for bioremediation of heavy metals in waste water.

The immobilization of Bombax Costatum Calyx biomasses involves the trapping of the biomass within the matrix of the polymer with sodium alginate and calcium chloride solutions to give a good biosorbent materials. However, biosorbents are hard enough to withstand the application of pressures, have water retention capacity, high and fast sorption uptake [10]. Also because of immobilization, the biosorbents so obtained offer easy and convenient usage compared to free biomass, which is easily biodegradable [6]. One of the most valued properties of IBCC is its water absorbency and dehydration behaviour [12]. It also exhibit suitable hydrophilicity and high swelling capacity. The target in this study is to immobilized the calyx of Bombax Costatum with sodium alginate with the objective of using the products as a sorbent for the removal of heavy metals in waste water.

\subsection{MATERIALS}

\section{Materials And Methods}

Sodium alginate, Calcium chloride, Sodium hydroxide, Hydrochloric acid, Lead nitrate, Ferric chloride, Cadmium (II) nitrate, Chromium (III) nitrate, Zinc nitrate and were obtained from the British Drug House(BDH).The chemicals were of analytical grade and were used as supplied. Bombax costatum Calyx was obtained from Kirawa town, Gwoza LGA Borno state Nigeria.

\subsection{METHODS}

\subsubsection{Preparation of Bombax Costatum Calyx Sample.}

The Bombax Costatum calyx sample was sundried, decoated and milled into powder, then sieved through a $100 \mu \mathrm{m}$ sieve screen to obtain fine powder and packaged separately in polyethylene bag for further use [34].

\subsubsection{Preparation of Sodium Alginate and Calcium Chloride Solutions.}

Sodium alginate was made by weighing $4.00 \mathrm{~g}$ and making it up to $100 \mathrm{~cm}^{3}$ mark with distilled water in a volumetric flask and left over night for complete dissolution to give $4 \% \mathrm{w} / \mathrm{w}$ solution. Calcium chloride $(0.12 \mathrm{M})$ was prepared by weighing $26.28 \mathrm{~g}$ into 1 litre volumetric flask and making it up to the mark with distilled water [2].

\subsubsection{Synthesis of Immobilized Bombax Costatum Calyx (IBCC).}

$25 \mathrm{ml}$ viscous layers of dissolved Bombax Costatum calyx sample was mixed with $25 \mathrm{ml}$ of $4 \%$ stock solution of Sodium Alginate and stirred vigorously for even mixing in $250 \mathrm{ml}$ beaker. The mixture was then transferred into another beaker containing $30 \mathrm{ml}$ of $0.12 \mathrm{M}$ Calcium chloride solution. The reaction was allowed retention time of $1 \mathrm{hr}$ for complete precipitation. The precipitated blend solid of the sample was filtered and dried at room temperature for $24 \mathrm{hrs}$. The dried solid was stored in polyethylene bag for further use [2].

The above procedure was followed by mixing another set of blend compounds with $4 \%$ of the stock solution of Sodium alginate and Bombax Costatum calyx in the ratio of 100:0, 95:5, 90:10, 85:15 and 80;20 which were designated as B1, B2, B3, B4and B5 respectively. The dried solids were separately stored in polyethylene bags for further use [2].

\subsubsection{Preparation of Synthetic waste water.}

The metal ions chosen for this study were $\mathrm{Pb}, \mathrm{Fe}, \mathrm{Cr}, \mathrm{Cd}$ and $\mathrm{Zn}$. The standards of these metal ion solutions were prepared from their salts by dissolving 1.60, 2.90, 7.70, 2.29 and $3.78 \mathrm{~g}$ of Lead nitrate, Ferric chloride, Chromium (III) nitrate, Cadmium (II) nitrate and Zinc nitrate in distilled water respectively and made 
up to 1 litre in a Volumetric flask that gave the stock solution of $1000 \mathrm{ppm}$ of the metal ions. Serial dilution of $200 \mathrm{ppm}$ of each metal ion solution was prepared with distilled water. The synthetic waste water was kept for further use [36].

\section{Sorption experiment using Immobilized Bombax costatum Calyx (IBCC).}

The experiments were carried out in the batch mode for the measurement of adsorption capacities. From $200 \mathrm{ppm}$ of each metal ion solution, $50 \mathrm{ml}$ was taken into a $25 \mathrm{ml}$ conical flask and $0.2 \mathrm{~g}$ of the IBCC was added corked with a rubber bung and shaken with a flask shaker for 2 hours at room temperature $\left(30^{\circ} \mathrm{C}\right)$ at 150rpm. The separation of the adsorbents and solutions were carried out by filtration with whatman filter paper No 42 and the filtrates were stored in Sample cans for use. The residual metal ion Concentrations were determined using Atomic Absorption Spectrophotometer AAS Pyeunicam Model SP9 [34, 36].

The percentage adsorption was calculated using the following equation

\%Adsorption $=\left[\left(\mathrm{C}_{\mathrm{i}}-\mathrm{C}_{\mathrm{f}} / \mathrm{C}_{\mathrm{i}}\right)\right] \times 100$

Where $\mathrm{C}_{\mathrm{i}}=$ Initial metal ion Concentration and $\mathrm{C}_{\mathrm{f}}=$ Equilibrium metal ion Concentration (mg/l) [35]

\subsection{Determination of the effect of pH on Sorption Capacity of IBCC.}

The Sorption Capacity of the $0.2 \mathrm{~g}$ of Immobilized Bombax costatum Calyx (IBCC) with 50ml of 200 ppm of various metal ion solutions at different $\mathrm{pH}$ values(1.0 to 6.0) were shaken for 2 hours using a flask shaker at $30^{\circ} \mathrm{C} .1 .0 \mathrm{M} \mathrm{HCl}$ and $1.0 \mathrm{M} \mathrm{NaOH}$ were used to adjust the $\mathrm{pH}$ of the solutions as the case may be. The residual metal ions were measured using Atomic Absorption Spectrophotometer AAS Pyeunicam Model SP9 [35].

\subsection{Determination of the effect of Contact time on Sorption Capacity of IBCC.}

The Sorption Capacity of IBCC for the various metal ions were determined. Set of samples consisting of $0.2 \mathrm{~g}$ of the dried IBCC and $50 \mathrm{ml}$ of the metal ion solutions were introduced into $250 \mathrm{ml}$ conical flasks, corked with rubber bungs and climbed on a flask shaker. As the samples were undergoing agitation on the shaker, they were removed one after the other at a predetermined time interval ranging from 0.5 to 24 hours at $30^{\circ} \mathrm{C}$. The solutions were filtered and analyzed for the residual metal ions using AAS [35].

\subsection{Determination of the effect of Initial metal ion Concentrations on Sorption Capacity of IBCC.}

The Sorption Capacity of various samples consisting of $50 \mathrm{ml}$ each of different metal ion concentrations ranging from $5 \mathrm{ppm}$ to $100 \mathrm{ppm}$, each containing $0.2 \mathrm{~g}$ of the dried IBCC were prepared and shaken for 2 hours on a flask shaker at $30^{\circ} \mathrm{C}$.The solutions were filtered and analyzed for residual metal ions using AAS [35].

\subsection{Determination of the effect of temperature on Sorption Capacity of IBCC.}

The Sorption Capacity of IBCC for the various metal ions was determined. Set of samples consisting of $0.2 \mathrm{~g}$ of the dried IBCC and $50 \mathrm{ml}$ of the metal ion solutions were inserted into $250 \mathrm{ml}$ conical flasks, corked with rubber bungs and climbed on a flask shaker and shaken for $2 \mathrm{hrs}$. As the samples were undergoing agitation on the shaker, they were removed one after the other at different temperatures ranging from $30^{\circ} \mathrm{C}$ to $80^{\circ} \mathrm{C}$. The solutions were filtered and analyzed for the residual metal ions using AAS [35].

\section{Results And Discussion}

The sorption capacity for the different metal ions using IBCC sorbent is shown in figure 1 . It is observed that the sorbent has different affinity degree of different metal ions with $\mathrm{Fe}^{3+}$ coming highest (98.65) and Zinc the least (80.28). The differences observed in the sorption capacities for different metal ions can be explained in terms of differences in hydration free energy, the ability of metal to form covalent bond with ligand, the metal polymeric cations within the matrix structure and the nature of the surface sites available [34]. 


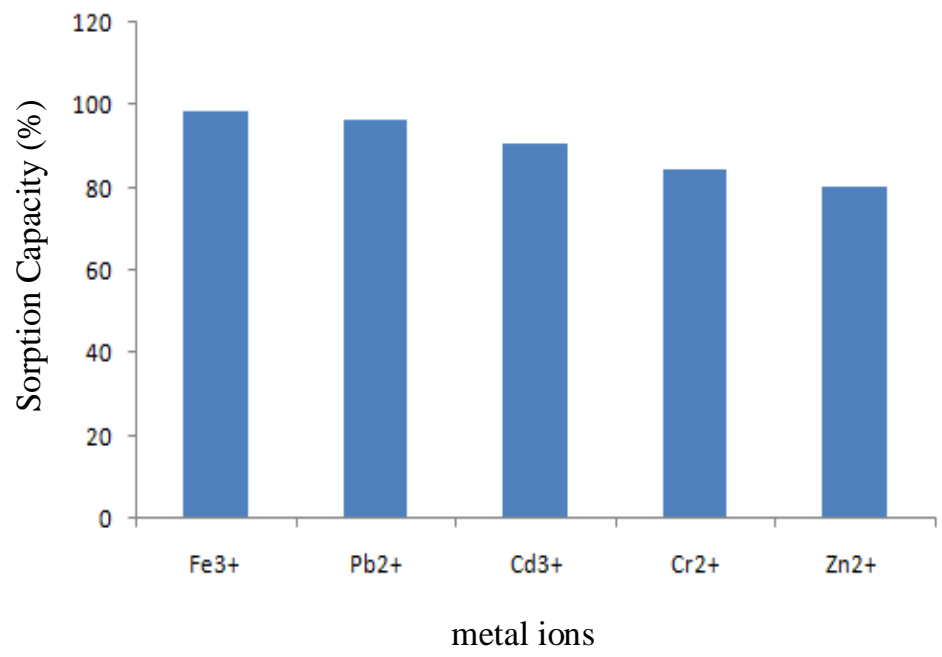

Fig. 1: Sorption capacity of metal ions by IBCC.

\subsection{Effects of $\mathrm{pH}$ on sorption capacity of IBCC.}

The effect of $\mathrm{pH}$ is important in the sorption process of the metal ions by different sorbents. Figure 2 depicts the effects of $\mathrm{pH}$ on the removal of metal ions. It can be seen that at low $\mathrm{pH}$ values, the sorption is low and as the $\mathrm{pH}$ of the solution increases the metal ion uptake increases, but at different level depending on the metal. The trend of result obtained was similar to the ones reported by [2, 12, 34-36]

The effect of $\mathrm{pH}$ on the maximum sorption capacity of the metal ions studied were 4 for $\mathrm{Cd}^{2+}, 6$ for $\mathrm{Pb}^{2+}$, and 5 for $\mathrm{Fe}^{3+}, \mathrm{Cr}^{3+}$, and $\mathrm{Zn}^{2+}$. The $\mathrm{pH}$ of the sorption media is related to the metal sorption - mechanism of the surfaces from the water and reflected the nature of the physicochemical interaction of the ions in solution and nature of the sorption sites [34]. Therefore, it can be suggested that the differences in the $\mathrm{pH}$ optima for different metal ions could probably be due to the different solution chemistry of the metal ion [12].

The $\mathrm{pH}$ influences the equilibrium metal ion uptake in aqueous solution. This happens because of counter reaction of the competiting hydrogen ion as well as the chemistry of the active binding sites of the sorbent [12]. Increasing the $\mathrm{pH}$ leads to precipitation of insoluble hydroxide or hydrated oxide, thereby lowering the metal ion availability for sorption. On the other hand, a decrease in $\mathrm{pH}$ results in the increase in the hydrogen ion concentration and hence possible competition for binding sites [20].

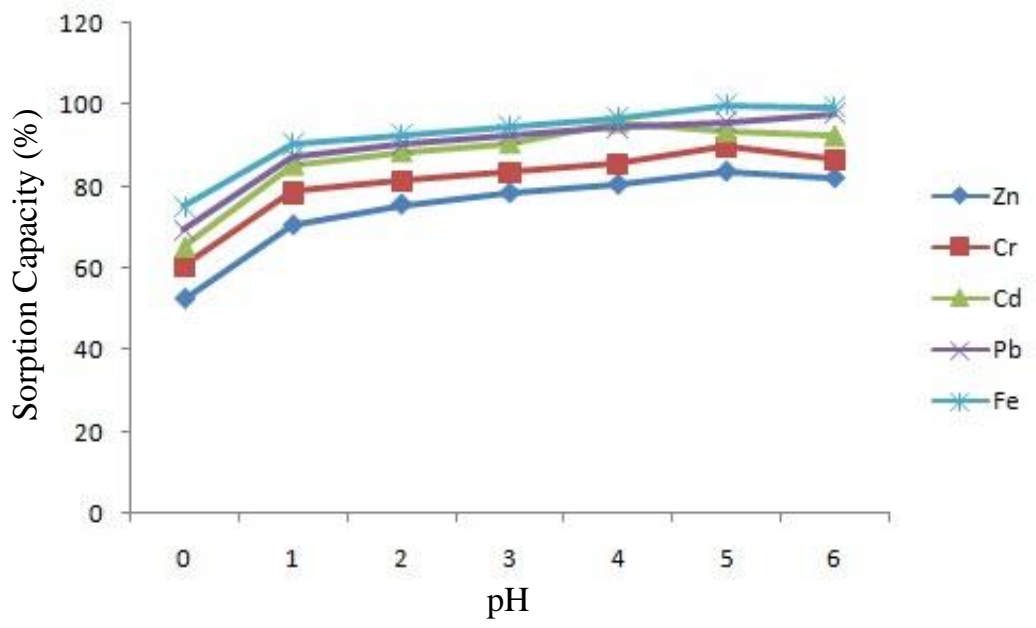

Fig. 2: Effect of $\mathrm{pH}$ on sorption capacity of IBCC

\subsection{Effect of Ionic Strength on Sorption Capacity of IBCC.}

Industrial wastes and natural water often contain dissolved salts which compete with heavy metal ions for binding sites on the sorbent carbon chain [9]. There is the need to ascertain the influence of this factor on IBCC. 
The effect of the ionic strength on removal of the heavy metal ions from the aqueous solution by IBCC is represented in Figure 3. It can be observed that the sorbent showed a decrease in sorption capacity with increase in ionic strength for all the metal ions studied. The decrease in sorption capacity with increasing ionic strength is primarily attributed to the reduction in difference in the ionic osmotic pressure between the sorbent and the external solution [6,9]. The difference in osmotic pressure between the sorbent and the external solution decreases as the ionic strength of external solution increases. Therefore, the sorption of metal ion decreases when the ionic strength of external solution increases [12]. From this experiment, the coexistence of metal ions in same solution caused the interference with the performance of IBCC sorbent. Therefore the pretreatment of the effluent to remove the interfering ion appears to improve the efficiency of the sorbent [19].

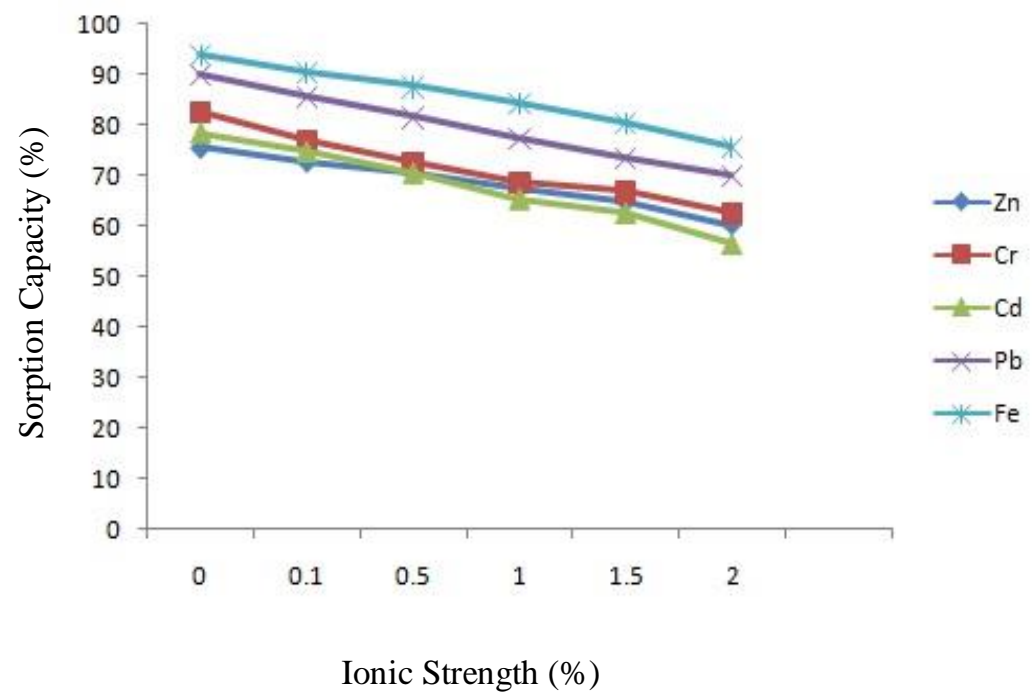

Fig. 3: Effect of ionic strength on sorption capacity of IBCC.

\subsection{Effect of Contact Time on Sorption Capacity of IBCC.}

The effect of contact time on sorption capacity of metal ions by IBCC is shown in Fig. 4. Equilibrium was established after 2 hours of contact time for all the metal ions, but high sorption rates were observed during the first 30 minutes. Equilibrium time of 30 minutes was recorded for $\mathrm{Pb}^{2+}$ and two hours for the rest of the metal ions. The rapid sorption of metal ions may be attributed to highly porous structure of the sorbent which provide readily access for large surface area for the sorption of the metal ions to the binding sites [21]. This result demonstrates that the sorbent (IBCC) can compete favourably with other industrial sorbents in terms of kinetics, hence, equilibrium time is one of the important parameters for an economical wastewater treatment system.

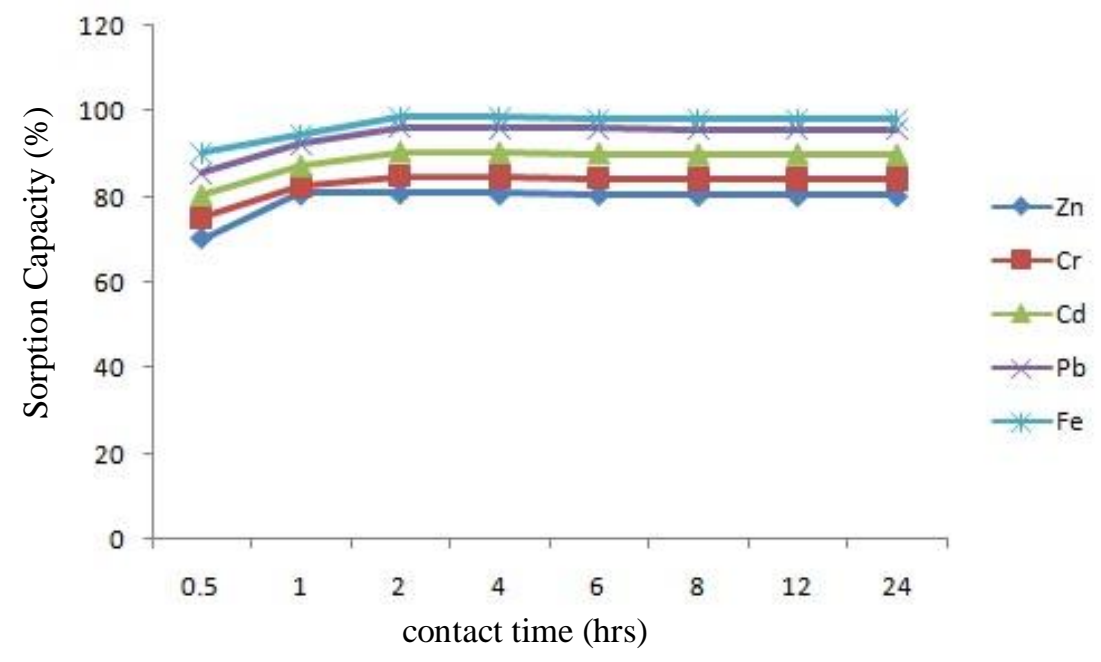

Fig. 4: The effect of the contact time on sorption capacity of IBCC. 


\subsection{Effect of Initial metal ion Concentration on Sorption Capacity of IBCC.}

The result of metal ions sorption by the IBCC as a function of initial metal ion concentration is shown in Fig. 5. It can be observed that the removal efficiency of the metal ions by the sorbent increases with the increase in initial concentration but leveled up however at certain point of the initial concentration.

This behaviour can be explained in term of increase in flux of the metal ions. The flux of the metal ions varies directly with the metal ion concentration and hence there should be an increase in flux with increase in initial concentration $[18,22,30]$. The constant requirement observed for all metal ions explained the point of saturation.

One of the problems of using conventional methods for the removal of the metal ions from aqueous systems is sometimes effectiveness, especially when the metal ion is present at a very low concentration [7]. The behaviour of IBCC even at low concentration 5ppm shows that it may be used in an attempt to improve the efficiency of metal ion removal from aqueous solution at low metal ion concentrations.

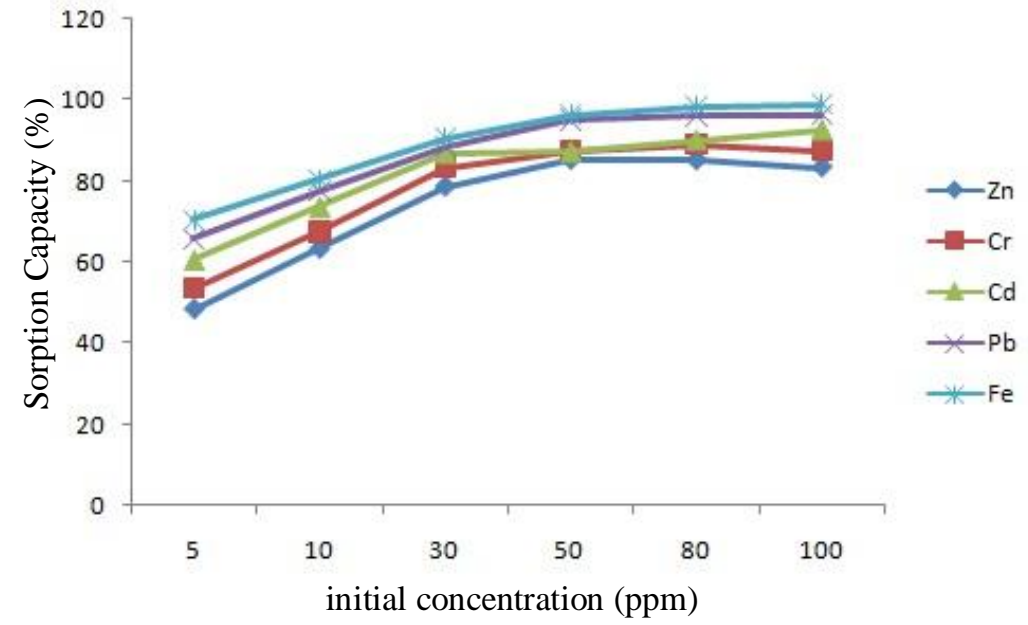

4.5 Effect of Temperature on sorption Capacity of IBCC.

Fig. 6 indicate the effect of temperature on the sorption of metal ions by IBCC. It can be seen that the sorption capacity decreases with an increase in temperature. The result of this work is in agreement with previous reports $[2,4,7,33,36]$. From the graph, it can be seen that the sorption capacity of the metal ions decreases sharply from $30^{\circ} \mathrm{C}$ to $50^{\circ} \mathrm{C}$. The decrease of the polymer matrix performance with increase in temperature may be due to the following factors:

i. The inherent molecular structure of the polymer matrix formed [36].

ii. Concentration of the immobilized sample molecules with increase in temperature to give a more compacted form of the polymer matrix which causes the pore to be narrower and suction sites be hidden or inaccessible to the water molecules [35].

iii. The sorption mechanism may be a physical adsorption Physical adsorption are normally exothermic, thus the extent of adsorption generally increases with decreasing temperature [2].

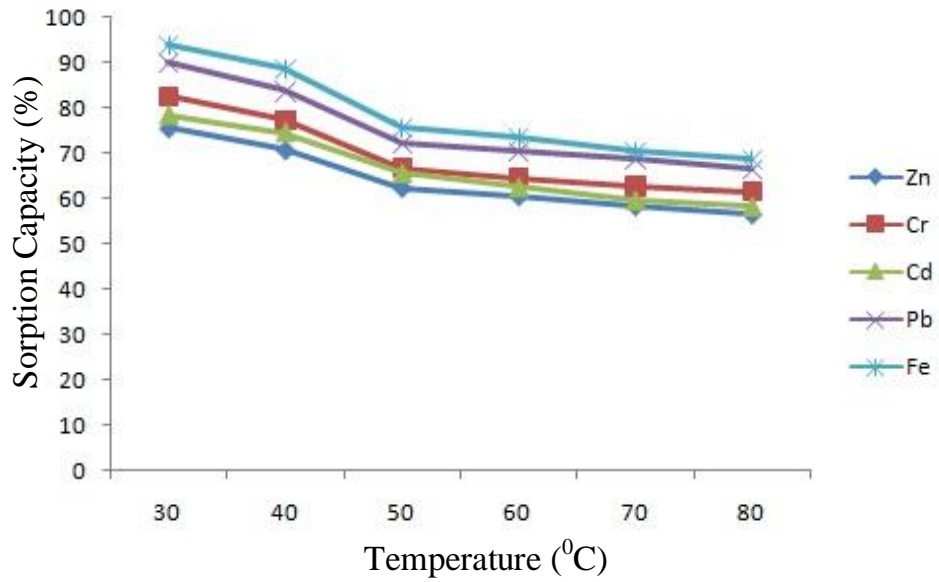

Fig. 6: Effect of temperature on sorption capacity of IBCC. 


\section{Conclusion}

The sorption of $\mathrm{Zn}, \mathrm{Cr}, \mathrm{Cd}, \mathrm{Pb}$ and $\mathrm{Fe}$ ions by IBCC has been shown to be dependent upon $\mathrm{pH}$, with best sosrption occurring between $\mathrm{pH} 5$ and6. This effect in $\mathrm{pH}$ suggests that the sorption mechanism may be an ion-exchange type process. Also, the sorption mechanism for these metals is a stable, rapid process which implies that the sorption is taking place on the cell wall surface of the Bombax costatum. The experiments have demonstrated that Bombax costatum calyx possessed the ability to bind appreciable amounts of $\mathrm{Zn}, \mathrm{Cr}, \mathrm{Cd}, \mathrm{Pb}$ and Fe ions as compared with other biosorbents. This ability to remove heavy metals from solution indicates the tremendous potential that the Bombax costatum calyx could have for cleaning the environment and industrial waste effluents from toxic metal ions.

\section{References}

[1] Zvinowanda, C. M. Okonkwo, J. O.; Shabalala, P. N.; Agyei, N. M., (2009). A novel adsorbent for heavy metal remediation in aqueous environments. Int. J. Environ. Sci. Tech., 6 (3), 425-434.

[2] Wuyep, P. A; Chuma, A. G., Awodi, S. and Nok A. J. (2007). Biosorption of Cr, Mn, Fe, Ni and Cu metals from refinery effluent by calcium alginate immobilized mycelia of polyporus squamosunolos; Sc. Res.Essay, 2(7): 217-221.

[3] Onundi, Y. B.; Mamun, A. A.; Al Khatib, M. F.; Ahmed, Y. M., (2010). Adsorption of copper, nickel and lead ions from synthetic semiconductor industrial wastewater by palm shell activated carbon. Int. J. Environ. Sci. Tech., 7 (4), $751-758$.

[4] Johncy Rani, Hemambika M. B., Hemapriya J. and Rajeshkannan V. (2010) Comparative Assessment of Heavy Metal Removal by Immobilized and Dead Bacterial Cells: A Biosorption Approach. Global J. of Env. Res. 4 (1): 23-33

[5] Innocent O. Emmanuel A. and Thomas A.(2009) Biosorption of Heavy Metal Ions from Aqueous Solutions Using a Biomaterial. Leo. J. of Sci.1583-0233 p 58-65

[6] Reza A. and Amin P. (2010) Removal of cerium (iv) ion from aqueous solutions using sawdust as a very low cost bioadsorbent Int J. Environ. Sci. Tech. Volume 5, Number 3: 253-262

[7] Korrapati Narasimhulu and Parcha Sreenivasa Rao (2009) Studies on removal of toxic metals from wastewater using pseudomonas species ARPN J. of Engn. and Appl. Sci. VOL. 4, NO. 7, 1819-6608.

[8] Villaescusa, I., Martinez, M. and Miralles, N. (2009). Heavy metal uptake from aqueous solution by cork and yohimbe bark wastes. J. Chem. Technol. Biotechnol.. 74, 812-816.

[9] Adeyinka, A., Liang, H. and Tina, G. (2007). "Removal of Metal Ion form Waste Water with Natural Waste" School of Engineering and Technology. 1-8. 33. Ibid 4.

[10] Tee T.W. and Khan A.R.M. (2008) Removal of Pb, Cd and $\mathrm{Zn}$ by waste tea leaves. Environmental Technology Letter, 9 12231232

[11] Wafwoyo W, Seo CW and Marshall WE (2008). Utilization of peanut shells as adsorbents for selected metals. J. Chem. Technol. Biotechnol. 74 1117-1121.

[12] Abdus-salam, N.; Adekola, F. A., (2008). The influence of Ph and adsorbent concentration on adsorption of lead and zinc on a natural goethite. Afr. J. Sci. Tech., 6, 55-66.

[13] Erdem, E.; Karapinar, N.; Donat, R., (2009). The removal of heavy metal cations by natural zeolites. Colloid Interf. Sci. 280 (2), 309-314.

[14] Jayaram, K.; Murthy, I. Y. L. N.; Lalhruaitluanga, H.; Prasad, M. N. V., (2009). Biosorption of lead from aqueous solution by seed powder of Strychnos potatorum L. Colloid Surf. B., 71 (2), 248-254.

[15] Aman, T.; Kazi, A. A.; Sabri, M. U.; Bano, Q., (2008).Potato peels as solid waste for the removal of heavy metal copper (II) from waste water/industrial effluent. Colloid. Surface. B., 63 (1), 116-121.

[16] Regine, H.S.F.V. and Volesky, B. (2009). Biosorption: A solution to pollution? Int. Microb. 3:17-24.

[17] Liu Z., Zhang F.S. (2009). Removal of lead from water using biochars prepared from hydrothermal liquefaction of biomass Journal of Hazardous Materials 167, 933-939.

[18] El-Ashtoukhy E.S.Z., Amin N.K., Abdelwahab O. (2008). Removal of lead (II) and copper (II) from aqueous E.S.Z. solution using pomegranate peel as a new adsorbent. Desalination, 223, 162-173

[19] Aydin H., Bulut Y., Yerlikaya C. (2008). Removal of copper (II) from aqueous solution by adsorption onto low-cost adsorbents. Journal of Environmental Management 87, 37-45

[20] Kahraman, S., Dogan, N. and Erdemoglu, S. (2008). Use of various agricultural wastes for the removal of heavy metal ions. Intnl. J. Environ. Pollut., 34, 275-284.

[21] Demirbas A. (2008). Heavy metal adsorption onto agro-based waste materials: A review. J. Hazard. Mater., 157, 220-229.

[22] Viraraghvan, T.; Rao, G. A. K., (2007). Adsorption of Cadmium and Chromium from wastewater by fly ash. Environ. Sci. Health, A $26(5), 721-753$

[23] Al-Qodah Z. (2006) Biosorption of heavy metal ions from aqueous solutions by activated sludge, Desalination 196 164-176. 10.1016/j.desal.2005.12.012

[24] Hawari H.A., Mulligan N.C. (2006) Biosorption of lead (II), cadmium (II), copper (II) and nickel (II) by anaerobic granular biomass, Biores. Tech. 97 692-700. 10.1016/j.biortech.2005.03.033

[25] Kumar U., Bandyopadhyay M. (2006) Sorption of cadmium from aqueous solution using pretreated rice husk, Biores. Tech. 97 104109. 10.1016/j.biortech.2005.02.027

[26] Shama S.A. Moustafa M.E. and Gad M.A. (2010) Removal of heavy metalsfrom Aqueous Solution Using Eichhornia Crassipes Port. Electrochim. Acta 28 125-133 133

[27] Saeed A., Akhter M.W., Iqbal M. (2005) Removal and recovery of heavy metals from aqueous solution using papaya wood as a new biosorbent,Sep. \&Purifi.Tech.452531.10.1016/j.seppur.2005.02.004

[28] Sheng P.X. Ting Y.P. Chen J.P and Hong L. (2004) Sorption of lead, copper, cadmium, zinc and nickel by marine algal biomass: characterization of biosorptive capacity and investigation of mechanisms, J. Colloid. InterfaceScience275131141.10.1016/j.jcis.2004.01.036

[29] Boonamnuayvitaya V. Chaiya C. Tanthapanichakoon W. and Jarudilokkul S.(2004) Removal of heavy metals by adsorbent prepared frompyrolyzed coffee residues and clay, Sep. \& Purifi. Tech. 35 11-22.10.1016/S1383-5866(03)00110-2 
[30] Meunier N. Blais J.F.and Tyagi R.D. (2004) Removal of heavy metals from acid soil leachate using cocoa shells in a batch counter - current sorption process, Hydrometallurgy 73 225-235. 10.1016/j.hydromet.2003.10.011

[31] Iqbal M. and Edyvean R.G.J. (2004) Biosorption of lead, copper and zinc ions on loofa sponge immobilized biomass of Phanerochaete chrysosporium, Min. Eng. 17 217-223. 10.1016/j.mineng.2003.08.014

[32] Kumar U., Bandyopadhyay M. (2006) Sorption of cadmium from aqueous solution using pretreated rice husk, Biores. Tech. 97 104109. 10.1016/j.biortech.2005.02.027

[33] Korrapati Narasimhulu and Parcha Sreenivasa Rao (2009) Studies on removal of toxic metals from wastewater using pseudomonas species ARPN J. of Engn. and Appl. Sci. VOL. 4, NO. 7, 1819-6608.

[34] Mahvi, A. H., (2008). Application of agricultural fibers in pollution removal from aqueous solution. Int. J. Environ. Sci. Tech., 5 (2), 275-285.

[35] Osemeahon, S. A, Barminas J. T. Aliyu B. A and Nkafamiya, I.I. (2008). Application of grafted membranes for sorption of Cd ${ }^{2+}$, $\mathrm{Fe}^{2+}$ and $\mathrm{Zn}^{2+}$ in aqueous solution. J. Pure \& Appl. 2(3):32-36

[36] Ogali R. E.; Akaranta, O. and Aririguzo, V. O.; (2008) Removal of some metal ion from aqueous solution using orange mesocarp, Afr. J. Biotechnol. Vol. 7 (17) pp3073-3076 